\title{
Isolation of Cellulolytic Bacillus subtilis Strains from Agricultural Environments
}

\author{
Yu-Kyoung Kim, ${ }^{1}$ Shin-Chan Lee, ${ }^{1}$ Young-Yun Cho, ${ }^{1}$ Hyun-Jeong Oh, ${ }^{2}$ and Young Hwan Ko ${ }^{3}$ \\ ${ }^{1}$ Division of Sustainable Agriculture Research, Jeju Agricultural Research and Extension Services, Jeju-do 697-828, Republic of Korea \\ ${ }^{2}$ Research Division, Bio-Agr Co. Ltd., Jeju-shi, Jeju-do 690-022, Republic of Korea \\ ${ }^{3}$ Department of Food Bioengineering, Jeju National University, Jeju-do 690-756, Republic of Korea
}

Correspondence should be addressed to Young Hwan Ko, yhkbl@cheju.ac.kr

Received 4 October 2011; Accepted 20 November 2011

Academic Editors: M. Feiss and M. T. Rowe

Copyright (C) 2012 Yu-Kyoung Kim et al. This is an open access article distributed under the Creative Commons Attribution License, which permits unrestricted use, distribution, and reproduction in any medium, provided the original work is properly cited.

The bioconversion of cellulose and hemicellulose to soluble sugars is important for global stabilization and a sustainable human society. Here, hundreds of cellulolytic bacteria were screened and isolated from soil, compost, and animal waste slurry in Jeju Island, South Korea. Among the isolates, three strains, SL9-9, C5-16, and S52-2, showing higher potential for practical uses were purified on carboxymethyl cellulose (CMC) agar plates and identified as Bacillus subtilis strains by morphological, physiological, and biochemical characterization and 16S rRNA gene analysis. The production patterns of cellulose or hemicellulose-degrading enzymes were investigated during cell culture. All three isolated strains produced CMCase, Avicelase, $\beta$-glucosidase, and xylanase enzymes, which suggested synergic cellulolytic systems in Bacillus subtilis. The enzymes showing CMCase, Avicelase, and xylanase activities existed in cell-free culture supernatant, meanwhile $\beta$-glucosidase activity was detected in cell debris suggesting that three of the enzymes, including CMCase, Avicelase, and xylanase, were extracellular, and $\beta$-glucosidase was cell membrane bound. The three isolates, SL9-9, C5-16, and S52-2, were not the same strains, presenting slight differences in biochemical characteristics, $16 \mathrm{~S}$ rRNA gene sequences, and cellulolytic enzyme activities.

\section{Introduction}

The bioconversion of cellulose to soluble sugars and glucose is catalyzed by a group of enzymes called cellulases that are produced by microorganisms [1].

These cellulolytic microorganisms play an important role in the biosphere by recycling cellulose, the most abundant and renewable biopolymer on Earth. The demand for microbial cellulases and related enzymes is growing more rapidly than ever before [2].

Fungal cellulases are produced in large amounts, which include all the components of a multienzyme system with different specificities and modes of action, that is, endoglucanases (or CMCase), exoglucanases (cellobiohydrolase), and $\beta$-glucosidases (or cellobiases), acting in synergy for the complete hydrolysis of cellulose [3-6]. Synergy between cellulase components during the hydrolysis of cellulose in
Trichoderma viride was first demonstrated by Giligan and Reese [7].

Synergic multienzyme systems are also expected in bacterial cellulase complexes. Cellulolytic bacteria include aerobes such as Pseudomonas and Actinomyces, facultative anaerobes such as Bacillus and Cellulomonas, and strict anaerobes such as Clostridium. Most of these bacteria produce mainly endoglucanases [8]. A variety of Bacillus species secrete cellulases, including strains of B. cereus [9], B. subtilis [10], B. licheniformis [11], Bacillus sp. KSM-330 [12], and alkaliphilic Bacillus [13]. In addition, a fairly common observation has been that bacilli lack a complete cellulase system, with primary activity being on carboxymethyl cellulose (CMCase, endoglucanase), and which do not hydrolyze crystalline cellulose [10]. However, in contrast, there are reports of certain Bacillus endoglucanases (CMCase) that have shown detectable activity on microcrystalline cellulose $[14,15]$. 
We isolated cellulase-producing Bacillus subtilis strains from soil, compost, and animal waste slurry and studied their cellulolytic enzymes. This paper reports the occurrence of these cellulolytic enzymes from Bacillus subtilis strains isolated from different habitats. According to the results, the strains possess microcrystalline cellulose-hydrolytic activity, cell-bound $\beta$-glucosidases, and hemicellulases in addition to endoglucanases.

\section{Materials and Methods}

2.1. Bacterial Strains. Three strains, Bacillus licheniformis KACC10476, B. pumilus KACC10917, and B. subtilis KACC10111, were obtained from Korean Agricultural Culture Collection (KACC, Rural Development Administration, Korea). Four strains, B. amylolicheniformis KCTC2105, B. licheniformis KCTC3045, B. pumilus KCTC3348, and B. subtilis KCTC3560, were obtained from Korean Collection for Type Cultures (KCTC, Korea Research Institute of Bioscience and Bioengineering, Korea). Three bacterial isolates were acquired in this study and deposited in the KACC under registration number KACC91232P for Bacillus subtilis SL9-9, KACC91229P for Bacillus subtilis C5-16, and KACC91233P for Bacillus subtilis S52-2.

2.2. Isolation of Bacteria Producing Cellulases. A total of 176 samples were collected from soil, compost, and animal waste slurry on Jeju Island, South Korea, and were screened for cellulolytic bacteria. The samples were stored at $4^{\circ} \mathrm{C}$ in the dark until use. After appropriate dilutions with sterile water, $1 \mathrm{~mL}$ each of the sample dilutions was spread onto carboxymethyl cellulose (CMC) agar plates that consisted of CMC, 10.0; yeast extract, 1.0; $\left(\mathrm{NH}_{4}\right)_{2} \mathrm{SO}_{4}, 2.5$; $\mathrm{K}_{2} \mathrm{HPO}_{4} \cdot 3 \mathrm{H}_{2} \mathrm{O}, 0.25 ; \mathrm{NaCl}, 0.1 ; \mathrm{MgSO}_{4} \cdot 7 \mathrm{H}_{2} \mathrm{O}, 0.125$; FeSO $4 \cdot 7 \mathrm{H}_{2} \mathrm{O}, 0.0025 ; \mathrm{MnSO} 4 \cdot 4 \mathrm{H}_{2} \mathrm{O}, 0.025$; agar, $10(\mathrm{~g} / \mathrm{L}$, each), and then the plates were incubated at $28^{\circ} \mathrm{C}$ for 2 days. The incubation temperature focused on mesophiles. The initial medium $\mathrm{pH}$ was adjusted to 7.0 if not specified. A few bacterial colonies were harvested and transferred to fresh CMC agar plates containing trypan blue. The plates were incubated at $28^{\circ} \mathrm{C}$ for 2 days, and the cellulolytic clones were detected by clear halos around the colonies [16]. Three clones were finally chosen based on their relatively higher cellulolytic activities among 309 cellulase-positive clones that showed good colonial development and visible clearing zones and were maintained on CMC agar.

2.3. Identification of Bacterial Isolates. The isolates were morphologically and physiologically characterized and identified up to genus level according to Bergey's Manual of Determinative Bacteriology (8th edition). An API $50 \mathrm{CHB}$ kit (BioMérieux, Lyon, France) was also used for the identification of Gram-positive bacteria. API strips were inoculated with $24 \mathrm{~h}$-grown cultures and then incubated at $28^{\circ} \mathrm{C}$. The results were read according to the manufacturer's instructions and compared with other known Bacillus subtilis strains obtained from KACC and KCTC. Standard procedures [17] were used to analyze the clones for motility, sporulation, catalase, and Gram reaction.
2.4. Analyses of $16 S$ rRNA Gene Sequences. Genes of $16 \mathrm{~S}$ rRNA were sequenced and compared for identification of the bacterial isolates. The bacterial cells grown on CMC agar were harvested and used for chromosomal DNA isolation according to the protocols [18]. The chromosomal DNA was used as a template for amplification of $16 \mathrm{~S}$ rRNA via the polymerase chain reaction (PCR). The primers used were 27F: 5' -AGAGTTTGATCATGGCTCAG-3' as a forward

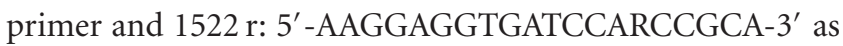
a reverse primer. The PCR reaction mixture was composed of $5 \mu \mathrm{L}$ of template $(50 \mathrm{ng} / \mu \mathrm{L}), 5 \mu \mathrm{L}$ of $10 \mathrm{x}$ reaction buffer ( $100 \mathrm{mM}$ Tris- $\mathrm{HCl}, 400 \mathrm{mM} \mathrm{KCl}, 500 \mu \mathrm{g} / \mathrm{mL}$ bovine serum albumin, $\mathrm{pH} 8.3), 5 \mu \mathrm{L}$ of deoxynucleoside triphosphates $(2.5 \mathrm{mM}$ each $), 1 \mu \mathrm{L}$ of each primer $(10 \mathrm{pmol} / \mu \mathrm{L}), 0.5 \mu \mathrm{L}$ of Taq DNA polymerase, and distilled sterile water to make final total volume of $50 \mu \mathrm{L}$. The reaction mixture was incubated in a thermocycler (GMI, Ramsey, Minnesota, USA) programmed to run 30 cycles repeatedly ( $1 \mathrm{~min}$ at $94^{\circ} \mathrm{C}$ for denaturation, $1 \mathrm{~min}$ at $55^{\circ} \mathrm{C}$ for annealing, and $1.5 \mathrm{~min}$ at $72^{\circ} \mathrm{C}$ for polymerization) and, finally, further incubated at $72^{\circ} \mathrm{C}$ for $10 \mathrm{~min}$ for DNA amplification. The molecular sizes of the resulting PCR products were analyzed on $1.0 \%$ agarose gel to confirm $1.5 \mathrm{~kb} 16 \mathrm{~S}$ rRNA. This $16 \mathrm{~S}$ rRNA was purified using a DNA purification kit (QIAGEN, Valencia, California, USA), and its nucleotide sequences were determined by the dideoxy chain-termination method [19] using a BigDye Terminator v3.0 Sequencing Kit (Amersham Pharmacia Biotech, Piscataway, New Jersey, USA). The 16S rDNA sequences were confirmed and compared through a BLAST nucleotide search provided by the National Center for Biotechnology Information (NCBI) GenBank (U.S. National Library of Medicine, Bethesda, Maryland, USA). The nucleotide sequence similarity of each isolate was obtained using the Gendoc program. These sequence data have been submitted to the GenBank databases under accession no. HQ236379 for SL9-9 isolate, HQ236380 for C5-16 isolate, and HQ236381 for S52-2 isolate.

2.5. Preparation of Cellulolytic Enzyme Solutions. Starter cultures were prepared by transferring cells with an inoculation loop from the CMC agar plates to $100 \mathrm{~mL}$ of CMC liquid medium, the initial $\mathrm{pH}$ of which was adjusted to 7.0 if not specified, in $500 \mathrm{~mL}$ Erlenmeyer flasks. Two days after shaking incubation at $28^{\circ} \mathrm{C}$, aliquots of $2 \mathrm{~mL}$ starter cultures were seeded into $200 \mathrm{~mL}$ of CMC liquid medium in $500 \mathrm{~mL}$ flasks. The flasks were further incubated on a shaker at $150 \mathrm{rpm}$ for 7 days at $28^{\circ} \mathrm{C}$. Cell growth was monitored by measuring optical density at $600 \mathrm{~nm}$. Culture samples were taken every $24 \mathrm{~h}$ during incubation, and their cellfree supernatants (CFSs) were obtained by centrifugation $(10,000 \times \mathrm{g}, 5 \mathrm{~min})$ and analyzed for cellulolytic activities. Meanwhile, the precipitated cells were suspended, washed in $5 \mathrm{~mL}$ of $0.05 \mathrm{M}$ phosphate buffer ( $\mathrm{pH}$ 6.5), and disrupted by sonication ( $150 \mathrm{~mA}, 20 \mathrm{~min})$. The resulting supernatant was removed after centrifuging $(12,000 \times \mathrm{g}, 30 \mathrm{~min})$ the sonicated cell suspension at $4^{\circ} \mathrm{C}$. The remaining cell debris (CD) was resuspended in $1 \mathrm{~mL}$ of $0.05 \mathrm{M}$ phosphate buffer ( $\mathrm{pH}$ 6.5) and assayed for cellulolytic enzyme activities. 


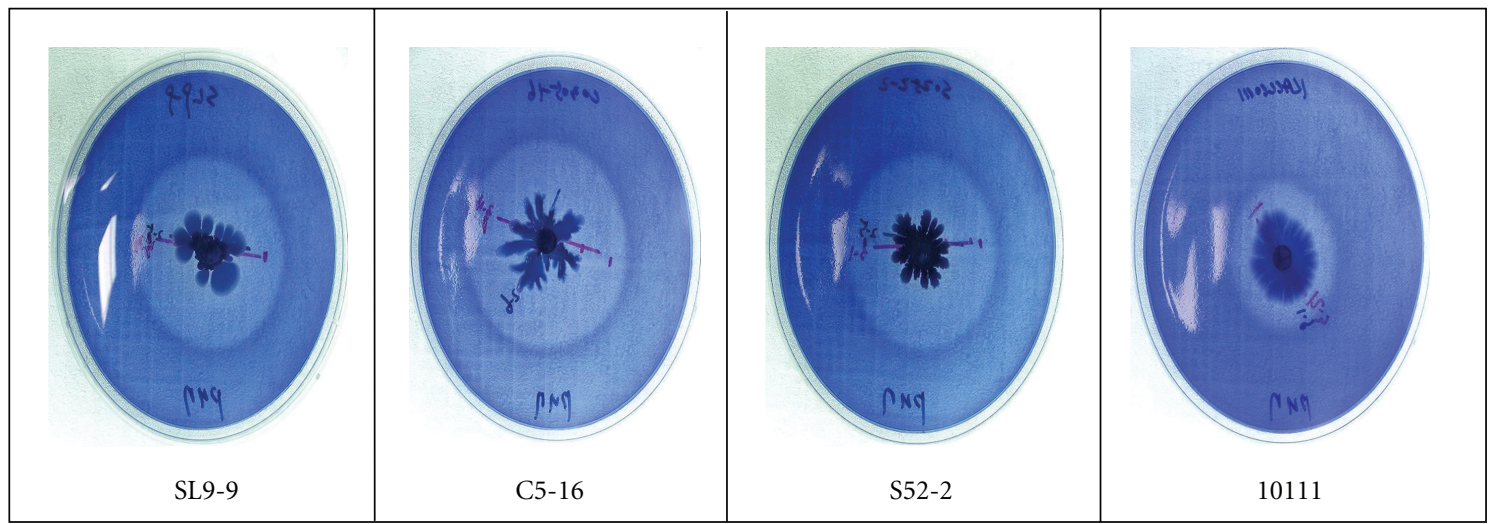

FIGURE 1: Bacterial cell growth and CMCase activity on CMC agar plates containing trypan blue. SL9-9, isolate from animal waste slurry; C5-16, isolate from compost; S52-2, isolate from soil; 10111, B. subtilis KACC10111. Clear halos resulting from cellulolytic activities could be detected around the colonies.

2.6. Enzyme Activity Assay. CMCase activity was measured by incubating $0.2 \mathrm{~mL}$ of enzyme solution with $0.5 \mathrm{~mL}$ of $1 \%$ $(\mathrm{w} / \mathrm{v})$ carboxymethyl cellulose, prepared in $0.1 \mathrm{M}$ sodium acetate buffer ( $\mathrm{pH} 5.0$ ), and $0.3 \mathrm{~mL}$ of $0.1 \mathrm{M}$ sodium acetate buffer ( $\mathrm{pH} 5.0$ ) for $10 \mathrm{~min}$ at $50^{\circ} \mathrm{C}$. The reducing sugars liberated were estimated by the 3,5-dinitrosalicylic acid (DNS) method [20]. The enzyme reaction was stopped by the addition of $3 \mathrm{~mL}$ DNS reagent (dinitrosalicylic acid $1 \mathrm{~g}$, $\mathrm{NaOH}, 16 \mathrm{~g}$, potassium sodium tartarate $300 \mathrm{~g}$, and distilled water up to $1 \mathrm{~L}$ ) to the above $1 \mathrm{~mL}$ reaction mixture, boiled in capped glass tubes for $5 \mathrm{~min}$, and cooled in cold water, and then optical density was measured at $540 \mathrm{~nm}$. The CMCase activity was determined using a calibration curve for Dglucose. One unit of CMCase activity was defined as the amount of enzyme that released $1 \mu \mathrm{mol}$ of reducing sugars as glucose equivalents $\mathrm{min}^{-1}$.

Avicelase activity was measured by incubating $0.5 \mathrm{~mL}$ of enzyme solution with $1 \mathrm{~g}$ of Avicel, a microcrystalline cellulose, as substrate and $1.5 \mathrm{~mL}$ of $0.1 \mathrm{M}$ sodium acetate buffer ( $\mathrm{pH} 5.0$ ) for $1 \mathrm{~h}$ at $50^{\circ} \mathrm{C}$. After incubation, the reaction mixture was centrifuged at $10,000 \times \mathrm{g}$ for $5 \mathrm{~min}$, and then $1 \mathrm{~mL}$ of the supernatant was taken to determine reducing sugars by the DNS method. One unit of Avicelase activity was defined as the amount of enzyme that released $1 \mu \mathrm{mol}$ of reducing sugars as glucose equivalents $\min ^{-1}$.

Filter paper-hydrolytic (FPase) activity was measured by a procedure [21] in which Whatman no. 1 filter paper was used as a substrate. Fifty milligrams of the substrate suspended in $1.5 \mathrm{~mL}$ of $0.1 \mathrm{M}$ sodium acetate buffer ( $\mathrm{pH} 5.0$ ) was incubated with $0.5 \mathrm{~mL}$ of enzyme solution at $50^{\circ} \mathrm{C}$ for $2 \mathrm{~h}$. After incubation, the reaction mixture was centrifuged at $10,000 \times \mathrm{g}$ for $5 \mathrm{~min}$, and then $1 \mathrm{~mL}$ of the supernatant was taken for the determination of reducing sugars by the DNS method. One unit of FPase activity was defined as the amount of enzyme that released $1 \mu \mathrm{mol}$ of reducing sugars as glucose equivalents $\min ^{-1}$.

$\beta$-glucosidase (or cellobiase) activity was measured by using $\rho$-nitrophenyl- $\beta$-D-glucopyranoside (pNPG) as a substrate. The hydrolysis of pNPG releases $\rho$-nitrophenol, a pigmented substance that can be measured spectrophotometrically at $400 \mathrm{~nm}$. The reaction mixture, containing $0.5 \mathrm{~mL}$ of
$1 \mathrm{mg} / \mathrm{mL} \mathrm{pNPG}, 0.5 \mathrm{~mL}$ of $0.05 \mathrm{M}$ sodium acetate buffer $(\mathrm{pH}$ 5.0 ), and $0.5 \mathrm{~mL}$ of enzyme solution, was incubated at $50^{\circ} \mathrm{C}$ for $1 \mathrm{~h}$. The enzyme reaction was stopped by adding $2 \mathrm{~mL}$ of $1 \mathrm{M} \mathrm{Na}_{2} \mathrm{CO}_{3}$, and the absorbance was measured at $400 \mathrm{~nm}$. One unit of $\beta$-glucosidase activity was defined as the amount of enzyme that released $1 \mu \mathrm{mol}$ of para-nitrophenol $\mathrm{min}^{-1}$.

Xylanase activity was measured by using Beechwood xylan as a substrate [22]. The reaction mixture containing $0.2 \mathrm{~mL}$ of crude enzyme, $0.5 \mathrm{~mL}$ of $1 \%$ xylan solution in $0.05 \mathrm{M}$ phosphate buffer ( $\mathrm{pH} 6.0$ ), and $0.3 \mathrm{~mL}$ of buffer ( $\mathrm{pH}$ 6.0) was incubated at $50^{\circ} \mathrm{C}$ for $10 \mathrm{~min}$. The enzymatic reaction was stopped by adding $3 \mathrm{~mL}$ of DNS reagent, boiled in capped glass tubes for $5 \mathrm{~min}$, and cooled in cold water for color stabilization. The resulting optical density was measured at $520 \mathrm{~nm}$. D-xylose was used as a standard for the preparation of a calibration curve. One unit of xylanase activity was defined as the amount of enzyme that released $1 \mu \mathrm{mol}$ of reducing sugars as xylose equivalents $\mathrm{min}^{-1}$.

\section{Results and Discussion}

3.1. Screening of Cellulolytic Bacteria. Cellulolytic bacteria were sought among 176 different samples collected from various environments such as soil, compost, and animal waste slurry on Jeju Island. Appropriate dilutions of each sample were placed on CMC agar plates. Positive clones showing good colonial development and a visible clearing zone were transferred to fresh CMC plates. A total of 309 positive clones were thus selected in the first round of screening. Their cellulolytic activities were confirmed by the trypan blue-staining method on CMC agar medium (Figure 1) and also by CMCase activity assay using cell-free supernatant obtained from the liquid cultures. The CMCase activities were examined and compared with those of other known Bacillus species obtained from KACC and KCTC. Finally, three clones showing relatively higher cellulolytic activity and broader $\mathrm{pH}$ optimum were selected (Figure 2). Their CMCase activities remained quite high around $\mathrm{pH} 5-8$, and the isolates were designated as SL9-9, C5-16, and S52-2, from the animal waste slurry, compost, and soil, respectively. 


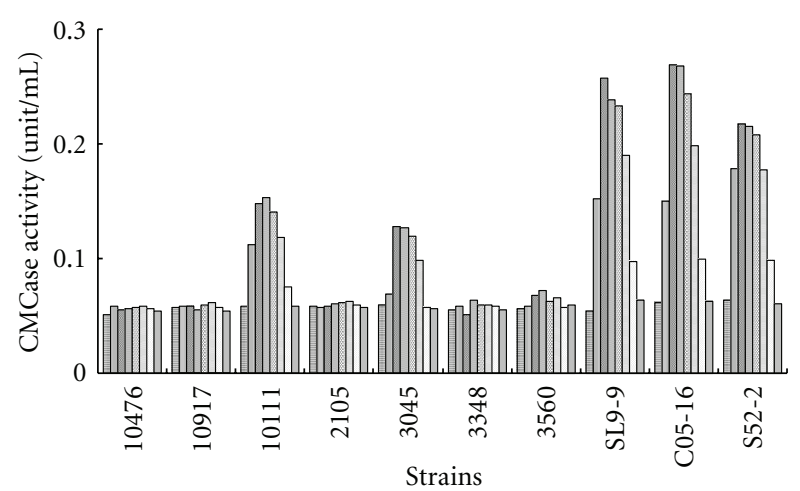

$\begin{array}{ll}\text { 圆 } \mathrm{pH} 3 & \square \text { pH5 } \\ \text { 图 } \mathrm{pH} 7 & \square \text { pH9 } \\ \square \text { pH4 } & \square \text { pH6 } \\ \square \text { pH8 } & \square \text { pH } 10\end{array}$

FIGURE 2: Comparison of carboxymethyl cellulase activity between Bacillus species at various cultivation $\mathrm{pH}$. 10476, B. licheniformis KACC10476; 10917, B. pumilus KACC10917; 10111, B. subtilis KACC10111; 2105, B. amylolicheniformis KCTC2105; 3045, B. licheniformis KCTC3045; 3348, B. pumilus KCTC3348; 3560, B. subtilis KCTC3560; SL9-9, isolate from animal waste slurry; C5-16, isolate from compost; S52-2, isolate from soil. Bacterial cells were grown in carboxymethyl cellulose (CMC) media with various initial $\mathrm{pH}$ at $28^{\circ} \mathrm{C}$ for 3 days in a shaking incubator, and then their CMCase activities in cell-free culture supernatants were measured.

TABLE 1: Morphological and physiological properties of the isolated cellulolytic bacteria.

\begin{tabular}{|c|c|c|c|}
\hline \multirow{2}{*}{ Characteristics } & \multicolumn{3}{|c|}{ Bacterial isolates } \\
\hline & SL9-9 & C5-16 & S52-2 \\
\hline Gram staining & Positive (+) & Positive (+) & Positive (+) \\
\hline Motility & + & + & + \\
\hline Catalase & + & + & + \\
\hline Cell shape & Rod & Rod & Rod \\
\hline Size $(\mathrm{L}, \mu \mathrm{m})$ & $2.5 \sim 3.0$ & $2.5 \sim 3.0$ & $2.5 \sim 3.0$ \\
\hline \multicolumn{4}{|l|}{ Colony appearance } \\
\hline Shape & Round & Round & Round \\
\hline Margin & Entire & Entire & Undulate \\
\hline Elevation & Umbonate & Umbonate & Umbonate \\
\hline Growth temp range $\left({ }^{\circ} \mathrm{C}\right)^{\mathrm{a}}$ & $15 \sim 50$ & $15 \sim 55$ & $15 \sim 50$ \\
\hline Growth pH range ${ }^{\mathrm{b}}$ & $5 \sim 10$ & $4 \sim 9$ & $5 \sim 9$ \\
\hline
\end{tabular}

${ }^{\mathrm{a}}$ Incubated for $72 \mathrm{~h}$; ${ }^{\mathrm{b}}$ Incubated for $48 \mathrm{~h}$.

3.2. Identification of Isolated Bacteria. Morphological and cultural studies revealed that all the clones were Grampositive and rod-shaped bacteria (Table 1). They were also catalase-positive, aerobic, moderate thermophiles. Their biochemical properties were further examined with an API 50CHB kit and compared with other Bacillus subtilis strains, namely, B. subtilis KACC10111 and B. subtilis KCTC3560 (Table 2). The three bacterial isolates showed slight differences from each other in such biochemical properties as methyl- $\alpha$-D-glucopyranoside, amygdalin, salicin, Dmaltose, D-lactose, inulin, glycogen, gentiobiose, and Dturanose utilization.

These three bacterial isolates were finally identified by $16 \mathrm{~S}$ rRNA gene sequence analysis. Their sequences were entered into the nucleotide-nucleotide BLAST (NCBI) system, and percentage identities were established. The highest identity for the isolate SL9-9 (accession no. HQ236379) was 99\% with the Bacillus subtilis strain BFAS (accession no. AY775778.1). The isolates C5-16 (accession no. HQ236380) and S52-2 (accession no. HQ236381) showed the highest identity at $99 \%$ with Bacillus subtilis strain CM19 (accession no. EU660332.1) and at $100 \%$ with Bacillus subtilis isolate C9-1 (accession no. EU257446.1), respectively. Based on their morphological, physiological, and genetic data, the three bacterial isolates were designated as Bacillus subtilis SL9-9, C5-16, and S52-2, respectively.

3.3. Production of Cellulolytic Enzymes by Bacterial Isolates. The three isolates were examined for CMCase, Avicelase, $\beta$-glucosidase, FPase, and xylanase production after cultivation in $200 \mathrm{~mL}$ of CMC liquid medium. Bacillus subtilis KACC10111, which showed higher CMCase activity than the other 6 Bacillus species obtained from KACC and KCTC (Figure 2), was used as a reference for enzyme activity comparisons.

Figure 3 shows the CMCase activity profiles obtained during shaking incubation for 7 days with $10 \mathrm{~g} / \mathrm{L}$ of carboxymethylcellulose as a carbon source. In the cell-free supernatant, both strains of SL9-9 and C5-16 showed considerable CMCase activity, reaching their maxima after $72 \mathrm{~h}$ of cultivation (0.9 and $0.8 \mathrm{unit} / \mathrm{mL}$, resp.), while the other two strains, S52-2 and KACC10111, presented relatively lower activities. The CMCase activities decreased slightly after $120 \mathrm{~h}$ of cultivation. Some differences in endo- $\beta$ 1,4-glucanase regulation among cellulolytic Bacillus species become apparent if one examines the timing of enzyme synthesis within a culture life cycle. There have been reports of cellulolytic enzyme synthesis during exponential growth [23] and after exponential growth [9, 10]. In the cell debris fraction, there was no observable CMCase activity (Figure 3(b)). Thus, CMCase was suggested as an extracellular enzyme.

Figure 4 shows the Avicelase activity profiles obtained during shaking incubation for 7 days with $10 \mathrm{~g} / \mathrm{L}$ of carboxymethyl cellulose as a carbon source. In the cell-free supernatant, all the strains produced considerable Avicelase activity and maintained maximum activity after $72-96 \mathrm{~h}$ of cultivation, although C5-16 showed a slight drop after $144 \mathrm{~h}$ of cultivation.

On a whole, SL9-9 presented higher activity than the other isolates from the beginning of cultivation. In the cell debris fraction, there was no definite Avicelase activity (Figure 4(b)). The profiles of Avicelase activity (Figure 4) were somewhat similar to those of CMCase activity (Figure 3). In addition, when the same Bacillus strains were examined for endo- $\beta$-1,4-glucanase activity using Whatman 
TABLE 2: Biochemical properties of the isolated cellulolytic bacteria.

\begin{tabular}{|c|c|c|c|c|c|}
\hline & & & & cains & \\
\hline Test $^{\mathrm{a}}$ & & & & B. subtilis & B. subtilis \\
\hline & & SL9-9 C5-16 S52-2 & & KACC 10111 & KCTC 3560 \\
\hline Control & - & - & - & - & - \\
\hline Glycerol & + & + & + & + & + \\
\hline Erythritol & - & - & - & - & - \\
\hline L-arabinose & + & + & + & + & + \\
\hline D-ribose & + & + & + & + & + \\
\hline D-xylose & + & $\mathrm{v}$ & $\mathrm{v}$ & + & $\mathrm{v}$ \\
\hline L-xylose & - & - & - & - & - \\
\hline D-adonitol & - & - & - & - & - \\
\hline D-glucose & + & + & + & + & + \\
\hline D-fructose & + & + & + & + & + \\
\hline D-mannose & + & + & + & + & + \\
\hline L-sorbose & - & - & - & - & - \\
\hline L-rhamnose & - & - & - & - & - \\
\hline Dulcitol & - & - & - & - & - \\
\hline Inositol & + & + & + & + & + \\
\hline D-mannitol & + & + & + & + & + \\
\hline D-sorbitol & + & + & + & + & + \\
\hline Methyl- $\alpha \mathrm{D}$-glucopyranoside & + & + & - & + & + \\
\hline $\mathrm{N}$-acetyl-glucosamine & - & - & - & - & - \\
\hline Amygdalin & + & + & - & + & $\mathrm{v}$ \\
\hline Arbutin & + & + & + & + & + \\
\hline Esculin ferric citrate & + & + & + & + & + \\
\hline Methyl- $\beta$-xylopyranoside & - & - & - & - & - \\
\hline D-lactose (bovine origin) & + & - & + & - & - \\
\hline D-arabinose & - & - & - & - & - \\
\hline Salicin & + & + & - & + & + \\
\hline D-cellobiose & + & + & + & + & + \\
\hline D-maltose & + & + & - & + & + \\
\hline D-melibiose & + & + & + & + & $\mathrm{v}$ \\
\hline D-saccharose & + & + & + & + & + \\
\hline D-trehalose & + & + & + & + & + \\
\hline Inulin & - & + & - & + & $\mathrm{v}$ \\
\hline D-melezitose & - & - & - & - & - \\
\hline Glycogen & + & + & - & + & + \\
\hline Xylitol & - & - & - & - & - \\
\hline Gentiobiose & - & $\mathrm{v}$ & - & - & $\mathrm{v}$ \\
\hline D-turanose & - & + & - & + & $\mathrm{v}$ \\
\hline D-lyxose & - & - & - & - & - \\
\hline D-tagatose & - & - & - & - & - \\
\hline D-fucose & - & - & - & - & - \\
\hline L-fucose & - & - & - & - & - \\
\hline D-arabitol & - & - & - & - & - \\
\hline Potassium gluconate & - & + & - & + & - \\
\hline Potassium2-ketogluconate & - & - & - & - & - \\
\hline D-galactose & - & - & - & - & - \\
\hline D-raffinose & + & + & + & + & $\mathrm{v}$ \\
\hline Potassium5-ketogluconate & - & - & - & - & - \\
\hline Methyl- $\alpha$ D-mannopyranoside & - & - & - & - & - \\
\hline AmiDon (Starch) & + & + & - & + & + \\
\hline L-arabitol & - & - & - & - & - \\
\hline
\end{tabular}




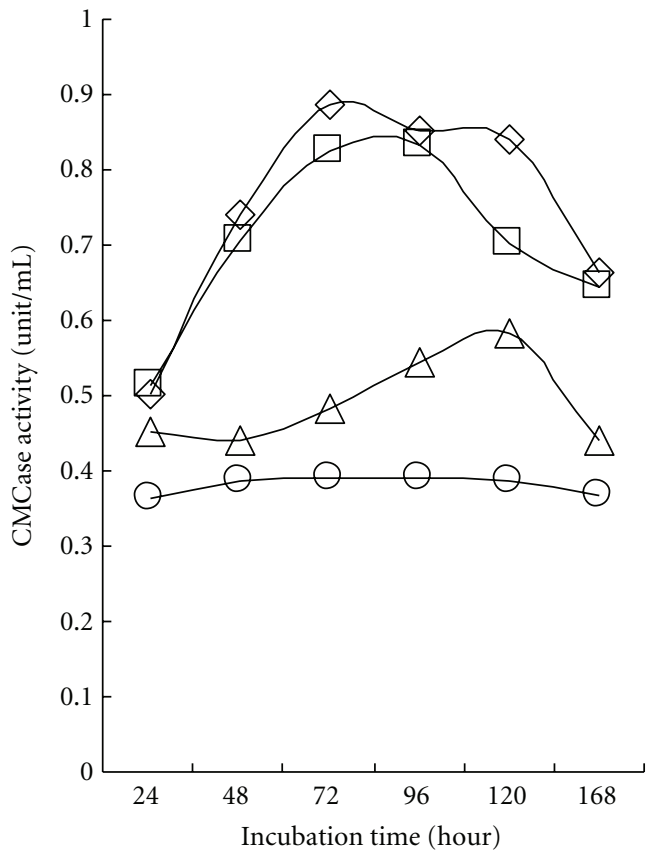

(a)

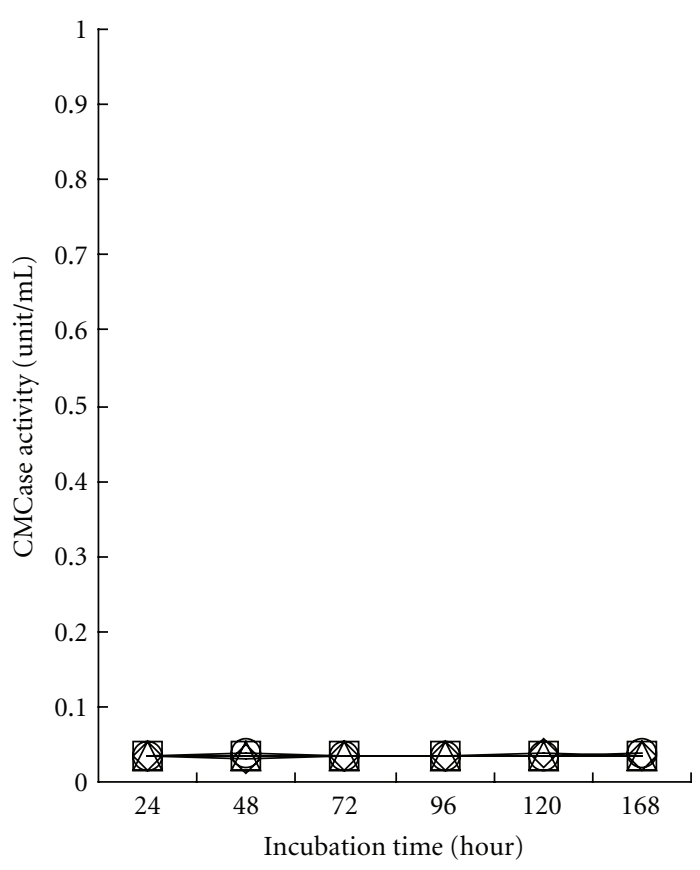

(b)

FIGURE 3: Carboxymethyl cellulase activity in cell-free culture supernatant (a) and cell debris (b) of isolated Bacillus subtilis strains. Bacterial cells (open rhombus, SL9-9; open square, C5-16; open triangle, S52-2; open circle, KACC10111) were grown in carboxymethyl cellulose (CMC) liquid medium ( $\mathrm{pH} 7.0$ ) on a shaker at $150 \mathrm{rpm}$ for 7 days at $28^{\circ} \mathrm{C}$. All cultures entered stationary phase in 5 days. Both cell-free culture supernatants (CFSs) and cell debris (CD) were assayed for CMCase activity. The mean values obtained from triplicate experiment were used to present results.

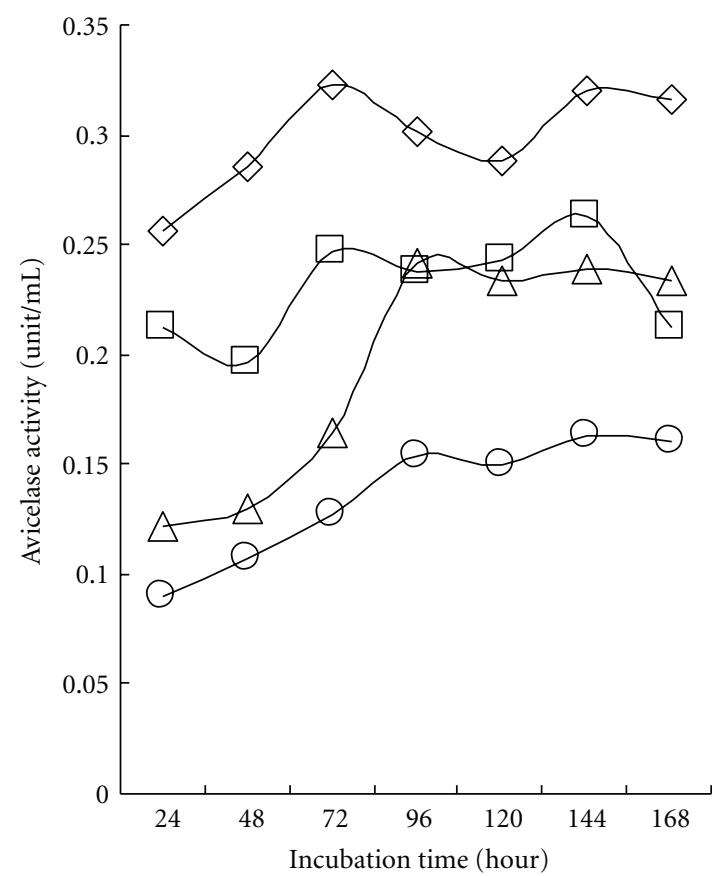

(a)

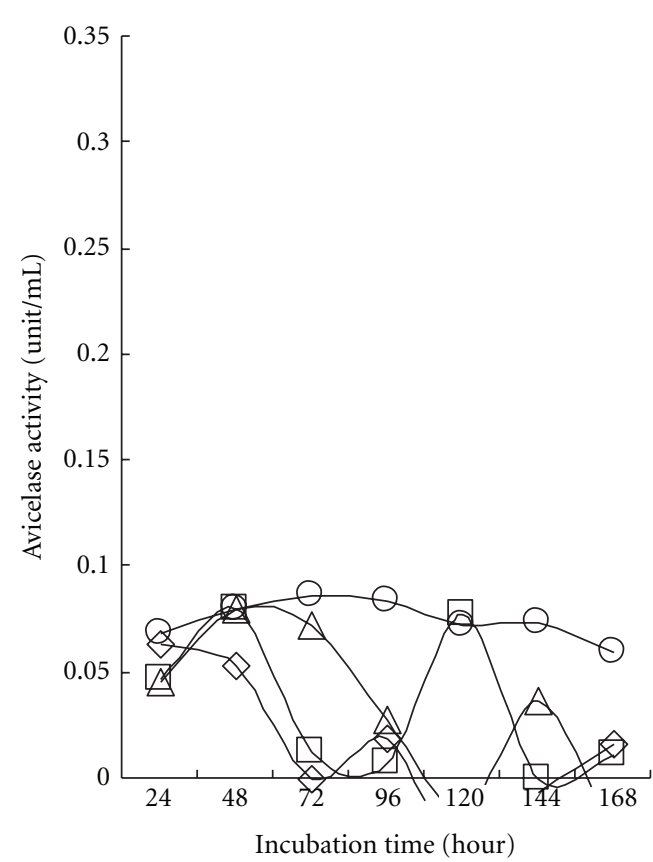

(b)

FIGURE 4: Avicelase activity in cell-free culture supernatant (a) and cell debris (b) of isolated Bacillus subtilis strains. Bacterial cells (open rhombus, SL9-9; open square, C5-16; open triangle, S52-2; open circle, KACC10111) were grown in carboxymethyl cellulose (CMC) liquid medium ( $\mathrm{pH} 7.0$ ) on a shaker at $150 \mathrm{rpm}$ for 7 days at $28^{\circ} \mathrm{C}$. All cultures entered stationary phase in 5 days. Both cell-free culture supernatants (CFSs) and cell debris (CD) were assayed for Avicelase activity. The mean values obtained from triplicate experiment were used to present results. 


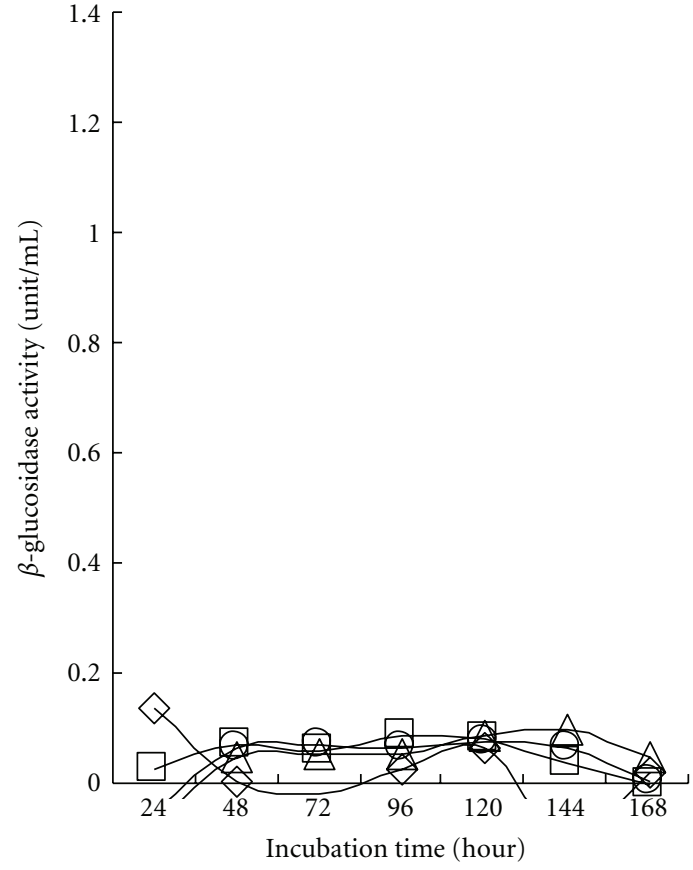

(a)

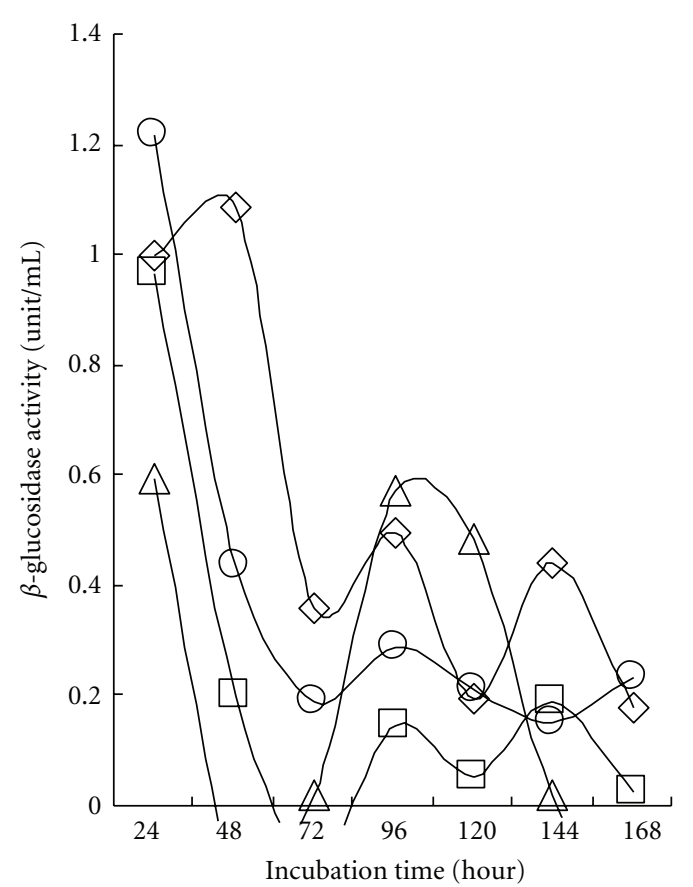

(b)

FIGURE 5: $\beta$-glucosidase activity in cell-free culture supernatant (a) and cell debris (b) of isolated Bacillus subtilis strains. Bacterial cells (open rhombus, SL9-9; open square, C5-16; open triangle, S52-2; open circle, KACC10111) were grown in carboxymethyl cellulose (CMC) liquid medium $(\mathrm{pH} 7.0)$ on a shaker at $150 \mathrm{rpm}$ for 7 days at $28^{\circ} \mathrm{C}$. All cultures entered stationary phase in 5 days. Both cell-free culture supernatants (CFSs) and cell debris (CD) were assayed for $\beta$-glucosidase activity. The mean values obtained from triplicate experiment were used to present results.

no. 1 filter paper as a substrate, low hydrolytic activity levels (0.025-0.030 unit $/ \mathrm{mL})$ were observed and slightly increased as cultivation continued like the Avicelase activity profiles (data not shown). It is highly possible that both the Avicelase and CMCase (endo- $\beta$-1,4-glucanase) activity resulted from the same enzyme protein. Our results show some contrast to a previous report [10] in which the endo- $\beta$-1,4-glucanase produced by $B$. subtilis DLG was not able to significantly degrade crystalline cellulosic substrates. Fukumori et al. [24] also reported that endo- $\beta$-1,4-glucanases from alkalophilic B. subtilis strains 1139 and N-4 were capable of hydrolysing CMC, but could not degrade Avicel significantly. Hamamoto et al. [25] suggested that a synergistic function of the $\mathrm{NH}_{2}$ terminus and $\mathrm{COOH}$-terminus of the endoglucanase in Clostridium cellulovorans is essential for the hydrolysis of crystalline cellulose. These phenomena suggest that crystalline cellulose-hydrolyzing activity does not depend on the same catalytic site of endo- $\beta$-1,4-glucanase.

Figure 5 shows the $\beta$-glucosidase (or cellobiase) activity profiles obtained during shaking incubation for 7 days with $10 \mathrm{~g} / \mathrm{L}$ of carboxymethylcellulose as a carbon source. In contrast to CMCase and Avicelase, no $\beta$-glucosidase activity was observed in the cell-free supernatant. However, all the strains showed considerable $\beta$-glucosidase activity in the cell debris fraction. Maximum activities (1.0, 1.0, 0.6, and 1.2 unit/mL for SL9-9 C5-16, S52-2, and KACC10111, resp.) were detected early after cultivation for $24 \mathrm{~h}$. The enzyme activities subsequently decreased after reaching maximum values, and then second rises and falls were observed. A reason for the rise and fall in $\beta$-glucosidase activity might be the negative regulation of $\beta$-glucosidase gene expression by glucose level (catabolite repression) in the cells. $\beta$ glucosidase activities are inferred to be related to membraneassociated enzymes. So far, $\beta$-glucosidase has scarcely been reported in Bacillus strains, although its production by other bacteria like Clostridium thermocellum [26] and Alcaligenes faecalis [27] has been documented. Bartley et al. [28] reported that $\beta$-glucosidase in actinomycete Microbispora bispora was cell membrane bound. Pajni et al. [29] reported that all 34 strains of cellulolytic Bacillus species isolated from soil produced xylanase, and $82.4 \%$ of them also produced $\beta$-glucosidase. On the other hand, Dhillon et al. [11] found that $B$. licheniformis could grow in minimal media containing cellobiose, but failed to show the presence of cellobiase in either the cellular fraction or culture supernatant. It was hypothesized that the utilization of cellobiose even in the absence of cellobiase involved the enzyme cellobiose phosphorylase [10].

The Bacillus strains SL9-9 and S52-2 showed considerable xylanase activity in the cell-free culture supernatant, and their activities reached maximum values (12.0 and 11.5 unit/mL, resp.) after shaking culture for $96 \mathrm{~h}$ with $10 \mathrm{~g} / \mathrm{L}$ of carboxymethylcellulose as a carbon source, as shown in Figure 6. The other two strains, C5-16 and KACC10111, presented lower overall activity from the beginning of cultivation. No xylanase activity was detected in the cell 


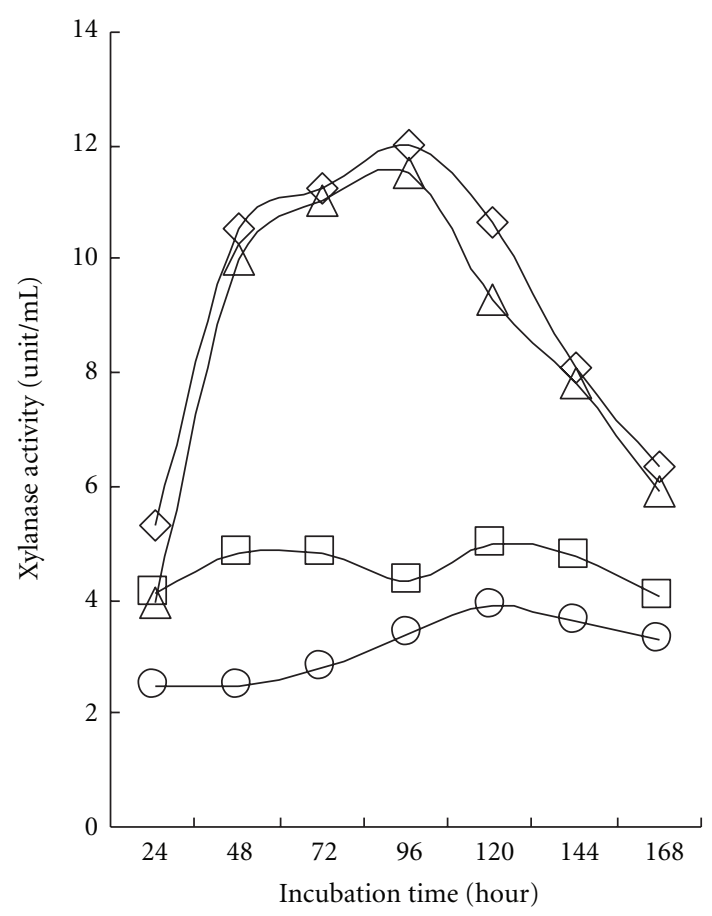

FIgURE 6: Xylanase activity in cell-free culture supernatant of isolated Bacillus subtilis strains. Bacterial cells (open rhombus, SL9-9; open square, C5-16; open triangle, S52-2; open circle, KACC10111) were grown in carboxymethyl cellulose (CMC) liquid medium ( $\mathrm{pH} 7.0)$ on a shaker at $150 \mathrm{rpm}$ for 7 days at $28^{\circ} \mathrm{C}$. All cultures entered stationary phase in 5 days. Both cell-free culture supernatants (CFSs) and cell debris (CD) were assayed for xylanase activity. No xylanase activity was detected in the CD fraction. The mean values obtained from triplicate experiment were used to present results.

debris fraction. Xylanase production has been previously reported in Bacillus strains [30]. Pajni et al. [29] reported that all examined cellulolytic Bacillus species were also xylanase positive, and units of xylanase activity were found to be much higher as compared to corresponding CMCase activity units. Xylans, with a linear backbone of $\beta$-1,4-linked xylose residues, form the major group of hemicelluloses. Endoxylanases hydrolyze xylan to xylooligosaccharides and xylose residues, while $\beta$-xylosidases catalyze the release of xylosyl residues by the terminal attack of xylooligosaccharides. It is highly possible that the xylanase activities of our Bacillus subtilis strains came from the combined actions of independent endoxylanase and $\beta$-xylosidase enzymes.

Three cellulolytic bacterial strains, SL9-9, C5-16, and S52-2, were isolated and identified as Bacillus subtilis in this study. The isolates were not the same strains, showing slight differences in biochemical characteristics, 16S rRNA gene sequences, and production patterns of cellulases and xylanases. They had microcrystalline cellulose-hydrolytic activity in addition to $\beta$-glucosidase, hemicellulase, and endoglucanase activities. These strains are presently being employed in agriculture as a fertilizer supplement. They especially were quite effective as ingredients of an organic seedbed.

\section{References}

[1] T. M. Wood and V. Garcia-Campayo, "Enzymology of cellulose degradation,” Biodegradation, vol. 1, no. 2, pp. 147-161, 1990.

[2] X. Li, H. Yang, B. Roy et al., "The most stirring technology in future: cellulase enzyme and biomass utilization," African Journal of Biotechnology, vol. 8, no. 11, pp. 2418-2422, 2009.

[3] M. K. Bhat and S. Bhat, "Cellulose degrading enzymes and their potential industrial applications," Biotechnology Advances, vol. 15, no. 3-4, pp. 583-620, 1997.

[4] B. Henrissat, H. Rodriguez, C. Viet,, and M. Schulein, "Synergism of cellulases from Trichoderma reesei in the degradation of cellulose," Biotechnology, vol. 3, no. 8, pp. 722-726, 1985.

[5] J. Knowles, P. Lehtovaara, and T. Teeri, "Cellulase families and their genes," Trends in Biotechnology, vol. 5, no. 9, pp. 255-261, 1987.

[6] T. M. Wood and S. I. McCrae, "The cellulase of T. koningii; Purification and properties of some endoglucanase components with special reference to their action on cellulose when acting alone and in synergism with the cellobiohydrolase," Biochemical Journal, vol. 171, no. 1, pp. 61-72, 1978.

[7] W. Giligan and E. T. Reese, "Evidence for multiple components in microbial cellulases," Canadian Journal of Microbiology, vol. 1, no. 2, pp. 90-107, 1954.

[8] T. M. Wood, "Properties of cellulolytic enzyme systems," Biochemical Society Transactions, vol. 13, no. 2, pp. 407-410, 1985.

[9] D. W. Thayer and C. A. David, "Growth of seeded cellulolytic enrichment cultures on mesquite wood," Applied and Environmental Microbiology, vol. 36, no. 2, pp. 291-296, 1978.

[10] L. M. Robson and G. H. Chambliss, "Characterization of the cellulolytic activity of a Bacillus isolate," Applied and Environmental Microbiology, vol. 47, no. 5, pp. 1039-1046, 1984.

[11] N. Dhillon, S. Chhibber, and M. Saxena, "A constitutive endoglucanase (CMCase) from Bacillus licheniformis-1," Biotechnology Letters, vol. 7, no. 9, pp. 695-697, 1985.

[12] K. Ozaki and S. Ito, "Purification and properties of an acid endo-1,4- $\beta$-glucanase from Bacillus sp. KSM-330," Journal of General Microbiology, vol. 137, no. 1, pp. 41-48, 1991.

[13] K. Horikoshi, "Alkaline cellulases from alkaliphilic Bacillus: enzymatic properties, genetics, and application to detergents," Extremophiles, vol. 1, no. 2, pp. 61-66, 1997.

[14] K. Aa, R. Flengsrud, V. Lindahl, and A. Tronsmo, "Characterization of production and enzyme properties of an endo- $\beta-1,4-$ glucanase from Bacillus subtilis CK-2 isolated from compost soil," Antonie van Leeuwenhoek, vol. 66, no. 4, pp. 319-326, 1994.

[15] C.-H. Kim, "Characterization and substrate specificity of an endo- $\beta$-1,4-D-glucanase I (Avicelase I) from an extracellular multienzyme complex of Bacillus circulans," Applied and Environmental Microbiology, vol. 61, no. 3, pp. 959-965, 1995.

[16] R. Berlemont, M. Delsaute, D. Pipers et al., "Insights into bacterial cellulose biosynthesis by functional metagenomics on Antarctic soil samples," The ISME Journal, vol. 3, no. 9, pp. 1070-1081, 2009.

[17] T. Gibson and R. E. Gordon, "Endosporeforming rods and cocci," in Bergey's Manual of Determinative Bacteriology, R. E. Buchanan and N. E. Gibbons, Eds., pp. 529-574, Williams \& Wilkins, Baltimore, Md, USA, 8th edition, 1974.

[18] F. M. Ausubel, R. Brent, R. E. Kingston et al., Current Protocols in Molecular Biology, Greene Publishing Associates and WileyInterscience, New York, NY, USA, 1993. 
[19] F. Sanger, S. Nicklen, and A. R. Coulson, "DNA sequencing with chain-terminating inhibitors," Proceedings of the National Academy of Sciences of the United States of America, vol. 74, no. 12, pp. 5463-5467, 1977.

[20] G. L. Miller, "Use of dinitrosalicylic acid reagent for determination of reducing sugar," Analytical Chemistry, vol. 31, no. 3, pp. 426-428, 1959.

[21] T. K. Ghose, "Measurement of cellulase activities," Pure and Applied Chemistry, vol. 59, no. 2, pp. 257-268, 1987.

[22] M. J. Bailey, P. Biely, and K. Poutanen, "Interlaboratory testing of methods for assay of xylanase activity," Journal of Biotechnology, vol. 23, no. 3, pp. 257-270, 1992.

[23] S. H. Park and M. Y. Pack, "Cloning and expression of a Bacillus cellulase gene in Escherichia coli," Enzyme and Microbial Technology, vol. 8, no. 12, pp. 725-728, 1986.

[24] F. Fukumori, T. Kudo, and K. Horikoshi, "Purification and properties of a cellulase from alkalophilic Bacillus sp. no. 1139," Journal of General Microbiology, vol. 131, no. 12, pp. 3339-3345, 1985.

[25] T. Hamamoto, F. Foong, O. Shoseyov, and R. H. Doi, "Analysis of functional domains of endoglucanases from Clostridium cellulovorans by gene cloning, nucleotide sequencing and chimeric protein construction," Molecular and General Genetics, vol. 231, no. 3, pp. 472-479, 1992.

[26] N. Ait, N. Creuzet, and P. Forget, "Partial purification of cellulase from Clostridium thermocellum," Journal of General Microbiology, vol. 113, no. 2, pp. 399-402, 1979.

[27] Y. W. Han and V. R. Srinivasan, "Purification and characterization of $\beta$-glucosidase of Alcaligenes faecalis," Journal of Bacteriology, vol. 100, no. 3, pp. 1355-1363, 1969.

[28] T. Bartley, C. Waldron, and D. Eveleigh, "A cellobiohydrolase from a thermophilic actinomycete, Microbispora bispora," Applied Biochemistry and Biotechnology, vol. 9, no. 4, pp. 337338, 1984.

[29] S. Pajni, N. Dhillon, D. V. Vadehra, and P. Sharma, "Carboxymethyl cellulase, $\beta$-glucosidase and xylanase production by Bacillus isolates from soil," International Biodeterioration, vol. 25, no. 1-3, pp. 1-5, 1989.

[30] J. X. Heck, P. F. Hertz, and A. Z. Ayub, "Cellulase and xylanase production by isolated amazon Bacillus strains using soybean industrial residue based solid-state cultivation," Brazilian Journal of Microbiology, vol. 33, no. 3, pp. 213-218, 2002. 

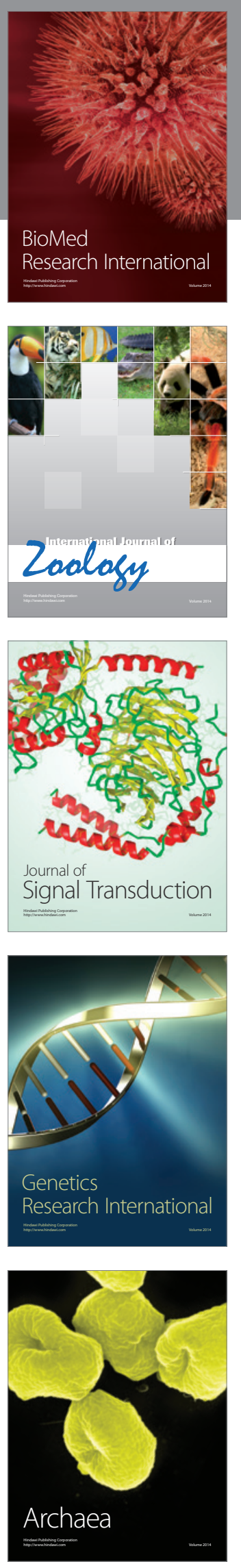
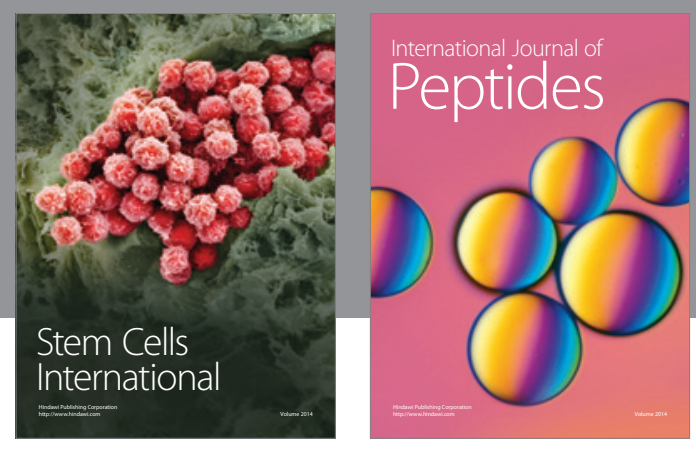

Submit your manuscripts at

http://www.hindawi.com
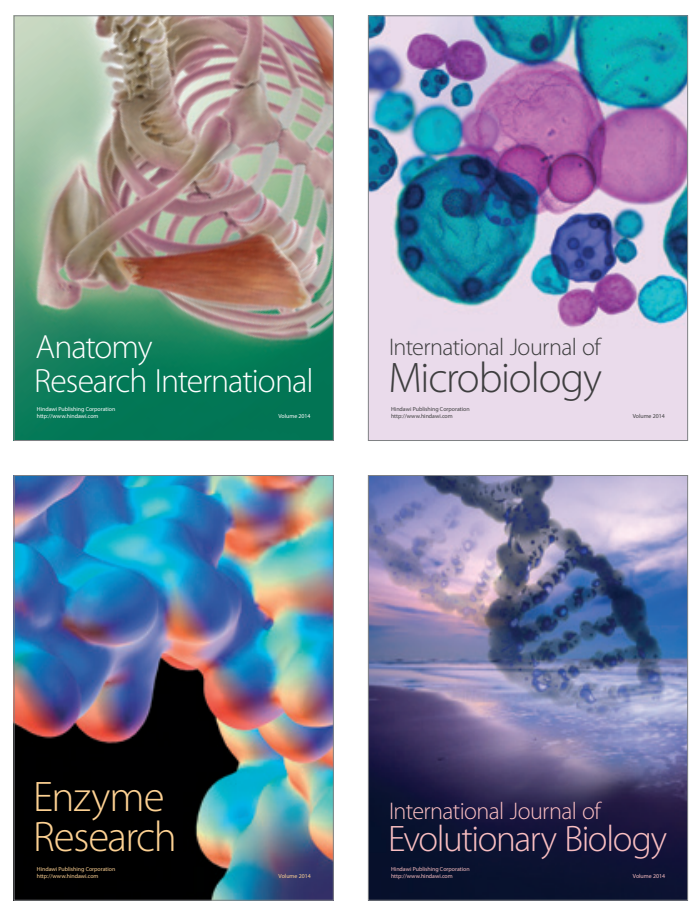
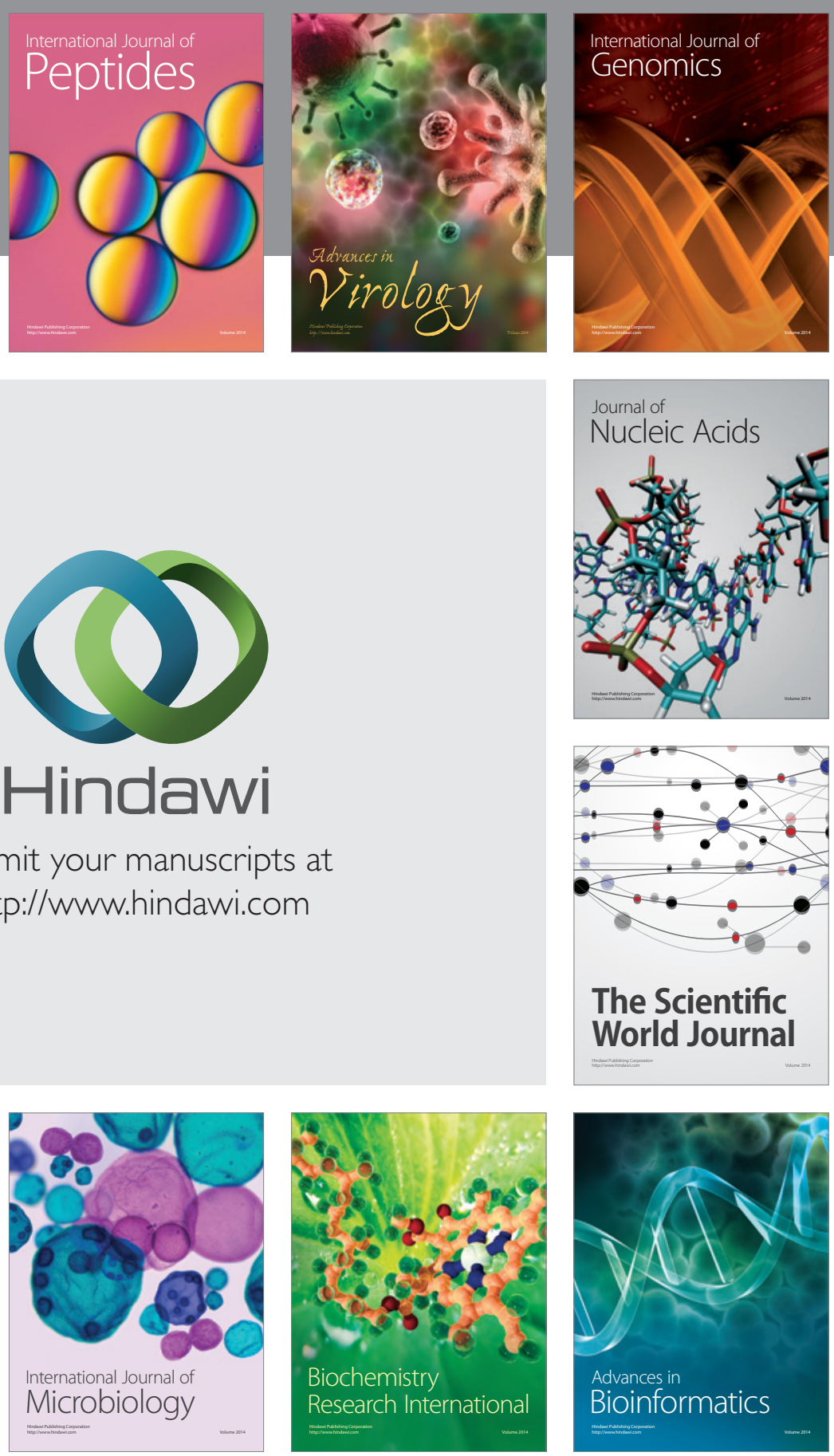

The Scientific World Journal
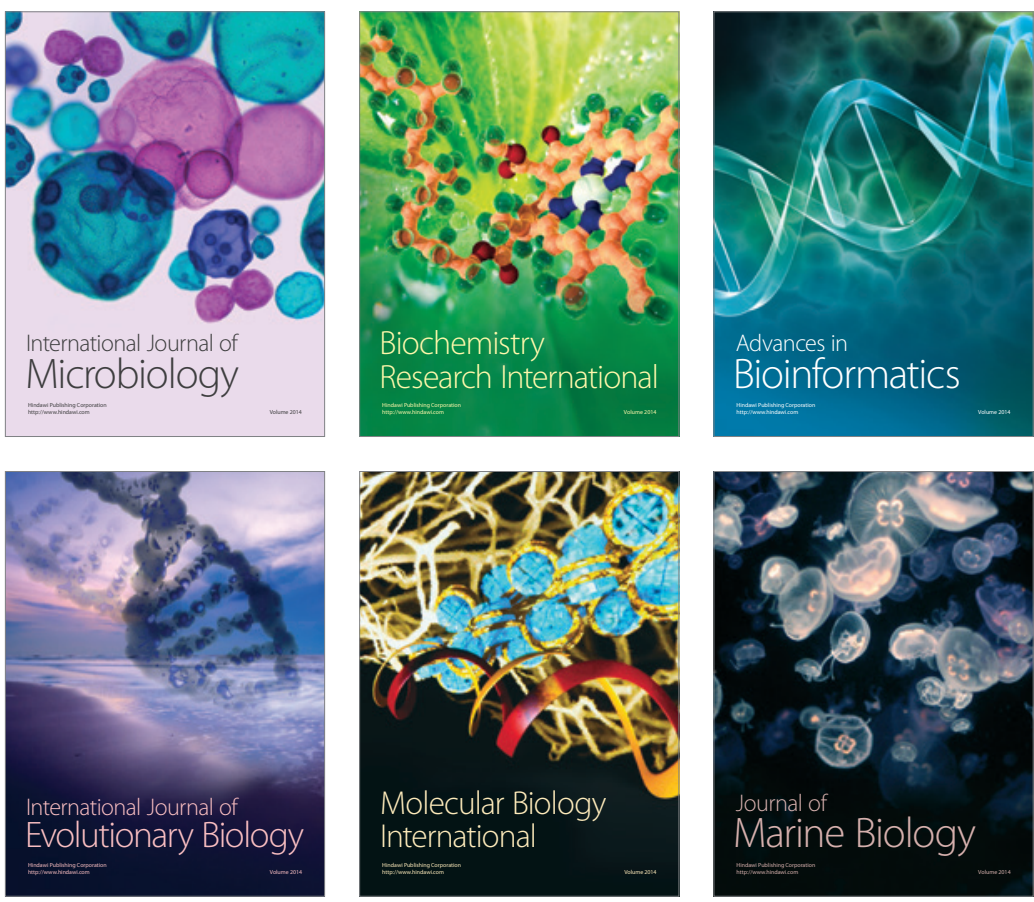